\title{
Annual Pattern on Abundance and Sex Ratio Distribution of Selected Fish Fauna of Ikere Gorge Reservoir, Oyo State, Nigeria
}

\author{
FESTUS IDOWU ADEOSUN \\ Department of Aquaculture and Fisheries Management, Federal University of Agriculture, Abeokuta, \\ PMB 2240, Ogun State, Nigeria \\ Corresponding author: adeosunfi@yahoo.com \\ Received: 13 November $2018 \quad$ Accepted: 17 April $2019 \quad$ Published: 30 June 2019
}

\begin{abstract}
Sex ratio affects the growth of wild population, thus, with the declining wild fish population, the study was designed to determine the effect of seasons on the sex ratio of fish population from Ikere Gorge, Nigeria for 18 months. Fish composition, diversity, distribution and abundance were determined according to standard methods. Sexes were determined and sex ratio was calculated using a standard method. A total of 5,823 fish specimens were caught during the period. The captured fish species were identified and classified into 34 species belonging to 13 families. The species richness was higher in the dry months than in the wet months. Fish diversity indices and evenness revealed a better diverse and even ecosystem in the wet season than the dry season. A marked significant difference $(\mathrm{p}<0.05)$ was observed between the species in the dry months than the wet season. Chrysichthyes nigrodigitatus $(35.07 \pm 7.59 \mathrm{a})$ was significantly $(\mathrm{p}<0.05)$ more abundant than the other species in the dry season. The sex ratio was skewed in favour of the female populations for $C$. nigrodigitatus, Tilapia melanopleura and Sarotherodon galilaeus but the reverse was the case for $L$. niloticus population. No monthly variation was observed in sex ratio of the species. The fish fauna from Ikere Gorge showed marked variations in the catch composition between the dry and wet months. $C$. nigrodigitatus and the Cichlids (Hemichromis fasciatus, S. galilaeus, Tilapia macrocephla and T. melanopleura) were present all year.
\end{abstract}

Keywords: Chrysichthyes nigrodigitatus, fish composition, Lates niloticus, Sarotherodon galilaeus, Tilapia melanopleura

Copyright: This is an open access article distributed under the terms of the CC-BY-NC-SA (Creative Commons Attribution-NonCommercial-ShareAlike 4.0 International License) which permits unrestricted use, distribution, and reproduction in any medium, for non-commercial purposes, provided the original work of the author(s) is properly cited.

\section{INTRODUCTION}

Sex population is the estimation of the abundance of any sex at any particular time under natural condition (Grayson et al., 2014). Sex ratio is a biological parameter that affects the growth rates and ecology of wild populations (Dyson \& Hurst, 2004), and it is fundamental to a sexually reproducing population (Gusmão et al., 2013). Adult sex ratio, that is the proportion of sexually mature males and females in a population, is a key demographic parameter (Le Galliard et al., 2005). There had been several reports on the skewedness of sex ratio in favour of either male or female population.

Food availability, predation, differential parental care, sex-specific differences in longevity or mortality, and even sex change can affect sex determination and resulting sex ratios (JiménezMelero et al., 2014; Fryxell et al., 2015). Skewed sex ratios are often observed in nature, across the tree of life and reasons attributed to the aforementioned. Also, among the various traits of natural populations, sex ratio is one of the most studied, and the theory of sex allocation is one of the most successful theories in evolutionary ecology (Gusmão et al., 2013).

Previous documentation on the reproductive biology of wild fish species had been reported. Reichard et al. (2014) on female bias in the adult sex ratio of African annual fishes. Seasonal changes in size, sex-ratio and body condition of the damselfish, Chromis chromis in the central Mediterranean Sea (Bracciali et al., 2014). Mian et al. (2017) on some reproductive aspects of freshwater Garfish, Xenentodon cancila from North-East Bangladesh. Adite et al. (2017) reported on the reproductive biology and life history patterns of the Claroteid, Chrysichthys nigrodigitatus from a man-made Lake in Southern Benin. 
Sex ratio can be used to determine the population growth rates and ecology trajectories of a wild population. Thus, gaining a better understanding of the population structure of the fish abundance as well as of the sex variations occurring throughout the year may be very useful in ensuring the early detection of environmental changes. This could also be useful for devising better management and conservation practices of natural water bodies. Also, knowledge of the sex ratio of fishes is important and provides information necessary in assessing the reproductive potential of any population (Jega et al., 2017). There is however, paucity of information on the distribution of fish sexes from the Ikere Gorge. Thus, there is a need to estimate the sex proportion of the fish species in this water body. This study was designed to estimate the annual pattern in the sex ratio of some economically important fish species from Ikere Gorge, Oyo State.

\section{MATERIALS AND METHODS}

\section{Study area}

Ikere Gorge is a man-made lake located in Ikere river, $8 \mathrm{~km}$ east of Ikere village and $30 \mathrm{~km}$ North east of Iseyin in Oyo state, Nigeria. Ikere river takes its source between longitude $8^{\circ} 10^{\prime}$ and $8^{\circ} 20^{\prime} \mathrm{E}$ and latitude $3^{\circ} 40^{\prime}$ and $3^{\circ} 50^{\prime} \mathrm{N}$. The reservoir has a capacity of 690 million $\mathrm{m}^{3}$ and a surface area of $47 \mathrm{~km}^{2}$.

Samples were collected from four locations in the study area (Figure 1) using ecological (flora and fauna) and hydrological characteristics (high and low water and water flow) and high intensity of fishing activity as selection criteria.

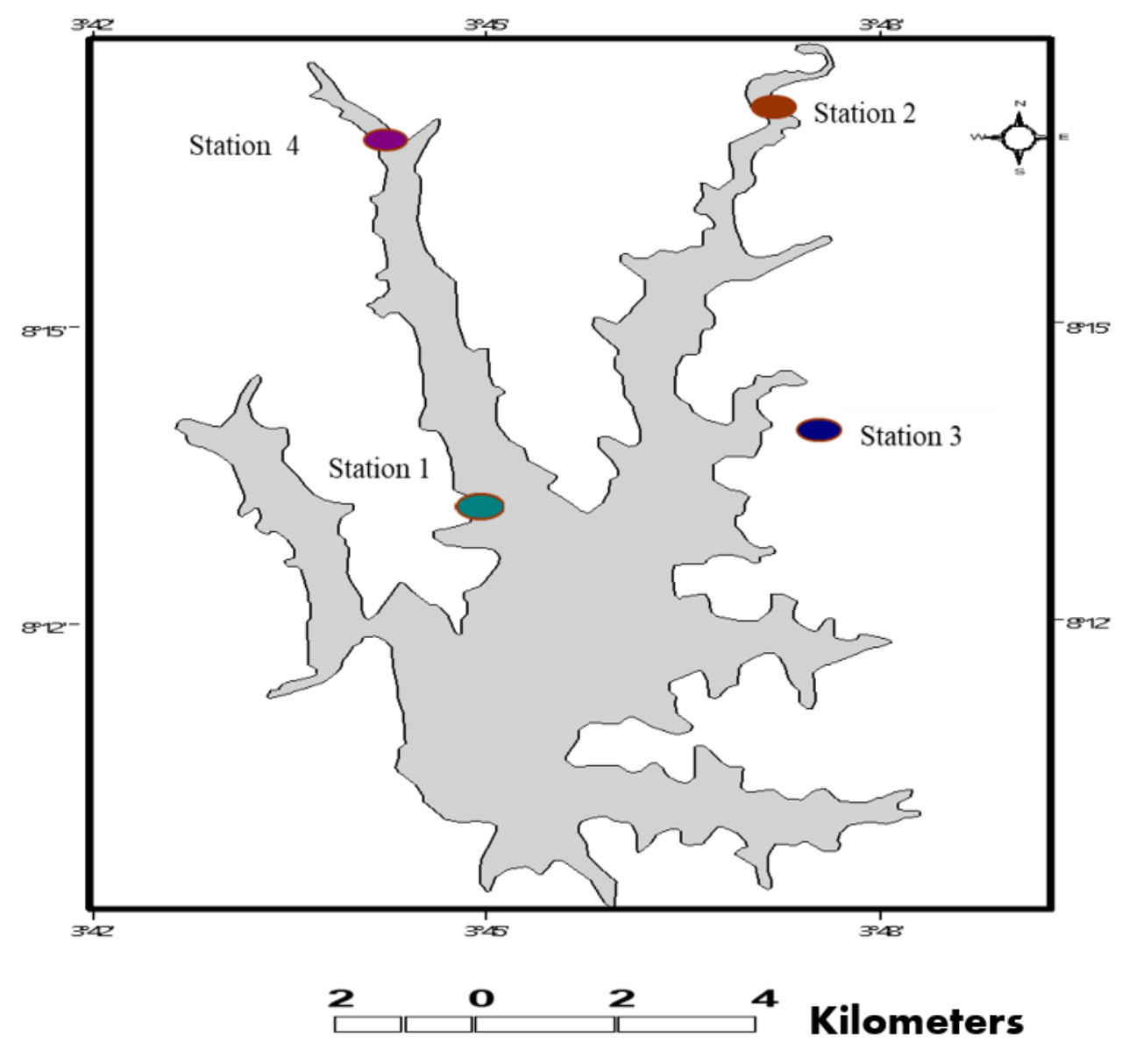

Figure 1. Map of Ikere Gorge showing sampling locations 
Station 1. This is the dam site of the gorge. It is characterized by high water and high fishing activities. This station is characterized by high flora and fauna community. Fishing villages selected were: Benue camp, Ilaje camp and Egun camp.

Station 2. Covers the Ikere river channel, which consists of flooded bush patches. It is characterized by low water with constant water flow and low water. Fishing villages selected include Abugaga, Elelu, Idoma and Hausa camp.

Station 3. This is open water that covers the in-shore and area occupied by the central or middle portion of the gorge. It covers about $70 \%$ of the lake surface area with an average depth of 10.8 metres. It is characterized by extend flood plain which is seasonally exposed during the draw- down period. This station is known for its high fishing activities. It has rich fauna and flora community. Fishing villages selected include Aba-asamu and Togolis camp.

Station 4. Covers the shallow bays location of the gorge, this is an intake tower of the gorge. It has a characteristic rich fauna and flora community and fishing activities always ongoing. The two fishing villages selected were: Bendel and Agatu camp, respectively.

\section{Sampling Method}

Sampling locations were selected using purposive sampling. Sampling of each station for fish composition and abundance was done on a monthly basis using a fleet of 8 graded experimental gillnets (mesh sizes 25.4, 38.1, $50.8,63.5,76.0,88.5,126.4$ and 177.2 millimeters) and cast net $(50.8 \mathrm{~mm})$ of surface area 50 square meter deployed at $5 \mathrm{~m}$ depth. Samples were taken on the first three days of the first week of every month covering eighteen calendar months of wet (April - September) and dry months (October - March). Gears were set at dusk and retrieved at dawn in all stations. Fish species identification and identification of sexes were carried out from landing sites. The nets were set in different ecological zones: in open water, flooded bush patches and shallow bays. Catches were also collected from longlines, fish traps, and hollow cylinders made from bamboo and set hooks to provide a comprehensive picture of fish species in the lake.

\section{Water Quality Assessment}

Temperature, dissolved oxygen and hydrogen ion concentrations of the various locations were measured in situ using the HANNA Multiparameter $\mathrm{pH} / \mathrm{ORP} / \mathrm{DO} / \mathrm{Pressure} / \mathrm{Temperature}$ Waterproof Meter, Model HI98196.

\section{Fish Composition, Distribution and Abundance}

Catch from landings were enumerated, examined, sorted to species level, and weight, length and biomass number of fish species recorded. Catches were labeled according to locations as station 1,2,3, and 4 and conveyed to the laboratory of the Department of Aquaculture and Fisheries Management in icechest for further studies. Fish samples were identified using taxonomic keys (Olaosebikan \& Raji, 1998). Species representation in each station and seasons were analyzed using statistical tools. Biodiversity of the water body was also investigated using the Simpson and Shannon-Weiner diversity indices.

\section{Sex Ratio}

Sexes of species of economic importance (Chrysichthys nigrodigitatus, Lates niloticus, Tilapia melanopleura, and Sarotherodon galilaeus) were determined according to Bahrami et al. (2015). The sexes of the sampled fish species were visually determined by the inspection of the gonads. While some samples could easily be discerned by mere observation of the reproductive organs, others were observed by making slits on the ventral side of the fish to expose the gonads. For juveniles and immature specimens, magnifying glasses were often used. Records of observations were kept.

\section{Data analysis}

One-way Analysis of Variance (ANOVA) followed by Duncan Multiple Range Test (DMRT) was carried out using Statistical Package for Social Science (SPSS) to analyze for mean and standard error of the mean of the fish species compositions in various stations. Percentage was used for monthly catch. Biodiversity indices were estimated using the equations adopted from Adeosun et al. (2019).

$$
\text { Simpson index }(\mathrm{D})=\frac{\sum \mathrm{n}(\mathrm{n}-1)}{\mathrm{N}(\mathrm{N}-1)}
$$

Simpson index of diversity $=(1-D)$

Simpson's reciproocal index $=\frac{1}{\mathrm{D}}$

Shannon Index $(\mathrm{H})=-\sum \mathrm{Pi} \operatorname{lnPi}$

Shannon's Equitability $(\mathrm{EH})=\mathrm{H} / \mathrm{InS}$ 
where,

$\mathrm{N}$ is Total number of organisms of all species found,

$\mathrm{n}$ is number of individuals of a particular species,

$\mathrm{D}$ is diversity index,

$i$ is an index number for each species present in a sample,

$\mathrm{pi}=\mathrm{ni} / \mathrm{N}$ is the number of individuals within a species i divided by the total number individuals (N) present in the entire sample.

$\Sigma$ is sum of the values for each species

$\mathrm{S}$ is total number of species.

Water parameters and sex ratio were analyzed using the Microsoft Excel.

\section{RESULTS}

\section{Water quality parameter indices}

Figure 2 shows the temperature range in all the locations all through the study period between $22-30^{\circ} \mathrm{C}$ with least temperatures observed in location 2 and in the month of January, 2005. Temperatures as low as $24^{\circ} \mathrm{C}$ were also observed in locations 1, 3 and 4 irrespective of season. Figure 3 shows DO content ranging from $2.2 \mathrm{mg} / \mathrm{l}$ in location 4 to $9.1 \mathrm{mg} / \mathrm{l}$ in location 2 while $\mathrm{pH}$ fluctuated all through the study and in all the locations ranging from 6.04 -8.5 (Figure 4).

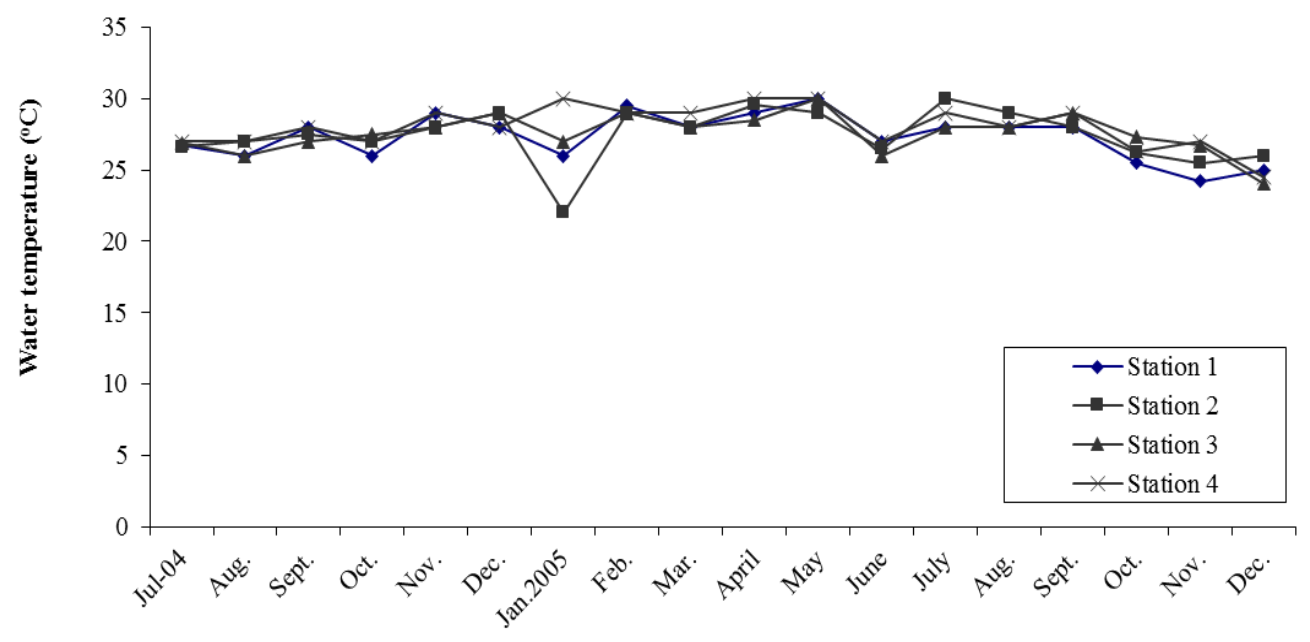

Months (July, 2004 - December, 2005)

Figure 2. Monthly variations in the water temperature of Ikere Gorge

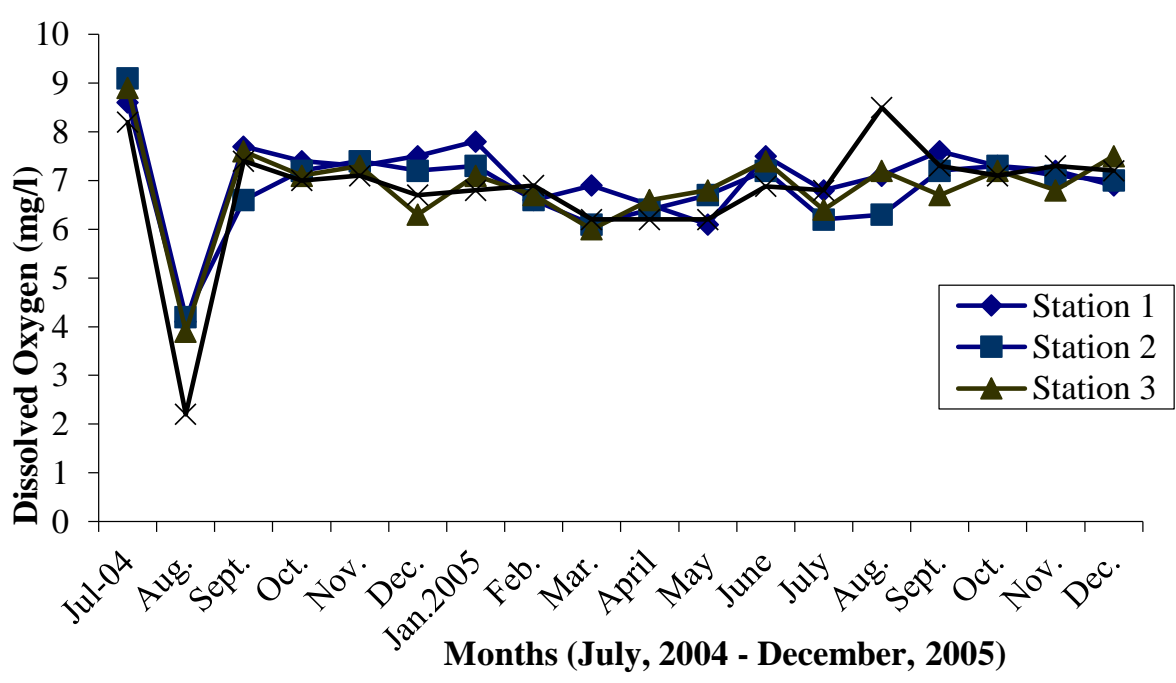

Figure 3. Monthly variations in dissolved oxygen of Ikere Gorge 


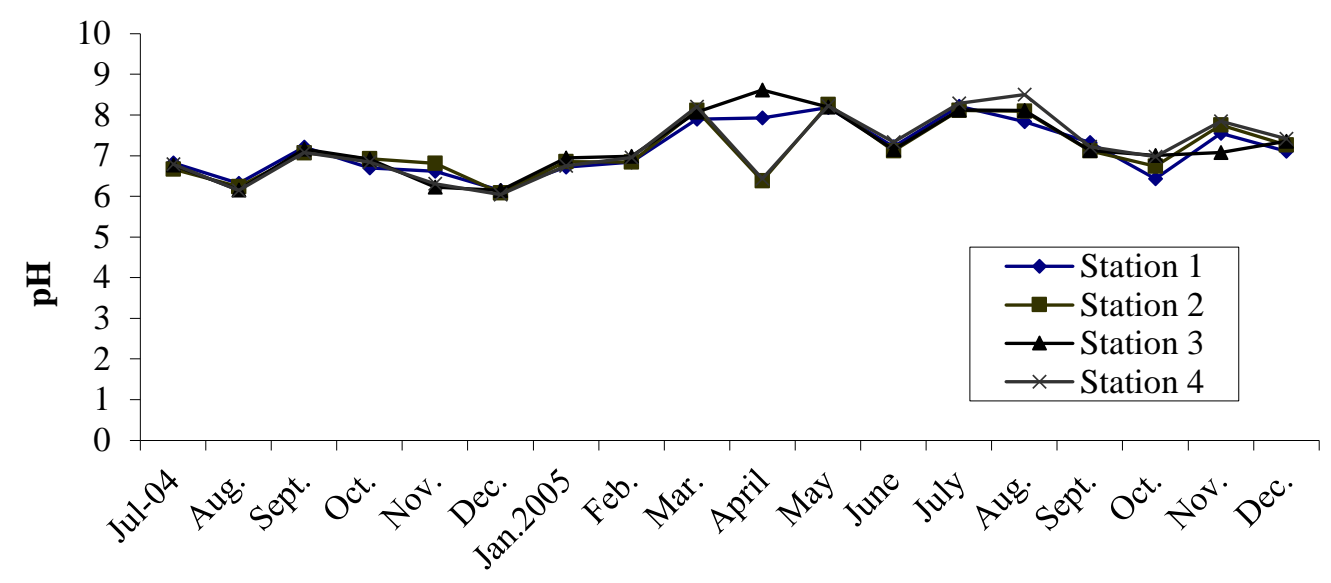

Month (July, 2004 - December, 2005)

Figure 4. Monthly variations in $\mathrm{pH}$ level of Ikere Gorge

\section{Fish Species and Harvest Composition}

A total of 5,823 fish specimen were caught during the 18 months of study. Station 4 had the highest catch 1,672 in number while the highest monthly catch was recorded in the months of December and January (Table 1). The captured fish were identified and classified into 34 species belonging to 13 families (Table 2). In the four stations of the study area, over 29 fish species were encountered in station 3, followed by 27 fish species in station 4, 26 fish species in station 1 and 24 in station 2.

A few fish species whose identification were not known and whose utility were highly negligible were however not included in the result. Species richness was higher in the dry months than in the wet months. Fish diversity indices and evenness revealed a better diverse and even ecosystem in the wet season than the dry season (Table 3).

\section{Monthly Distribution and Relative Abundance of Selected Species}

Marked significant difference was observed between the species in the dry months than the wet season (Table 4). L. niloticus was significantly lower than all other species in the dry season. $C$. nigrodigitatus was significantly $(\mathrm{p}<0.05)$ more abundant than the other species in the dry season. No significant difference was observed between
C. nigrodigitatus and the Cichlids in the wet season. This was not the case in the dry season.

Figure 5 shows monthly variation in abundance of the six selected commercial fish species. All six species were observed to be present in all sampling months. $C$. nigrodigitatus was more abundant in the dry months especially December - January. Presence of $L$. niloticus was almost zero especially at the onset of the rains. The Cichlids were in abundance in the wet months but more at the onset than in the dry months.

Figure 6 represents abundance of individual species in the different season. The figure reveals a significant difference $(\mathrm{p}<0.05)$ in the population of $C$. nigrodigitatus and $T$. macrocephala with the highest number observed in the dry season than the wet season.

\section{Sex Ratio of the commercial species of the study area}

\section{C. nigrodigitatus}

A total of 1423 specimens of $C$. nigrodigitatus were examined. In total, 606 were males while 817 were females. Figure 7 shows monthly variation in sex ratio during the sampling period. 
Table 1. Monthly biomass and number of fish caught in Ikere Gorge

\begin{tabular}{lcccccccc}
\hline & $\begin{array}{c}\text { No. of } \\
\text { fish }\end{array}$ & $\begin{array}{c}\text { Weight } \\
\text { (g) }\end{array}$ & $\begin{array}{c}\text { No. of } \\
\text { fish }\end{array}$ & $\begin{array}{c}\text { Weight } \\
\text { (g) }\end{array}$ & $\begin{array}{c}\text { No. of } \\
\text { fish }\end{array}$ & $\begin{array}{c}\text { Weight } \\
\text { (g) }\end{array}$ & $\begin{array}{c}\text { No. of } \\
\text { fish }\end{array}$ & $\begin{array}{c}\text { Weight } \\
\text { (g) }\end{array}$ \\
\hline July 04 & 113 & 5,995 & 38 & 2,064 & 82 & 2,561 & 42 & 1,255 \\
Aug. & 42 & 870 & 67 & 1,954 & 56 & 2,269 & 72 & 2,094 \\
Sept. & 45 & 1,498 & 77 & 5,026 & 62 & 4,150 & 60 & 3,935 \\
Oct. & 55 & 2,160 & 68 & 3,508 & 78 & 2,622 & 100 & 2,392 \\
Nov. & 68 & 3,791 & 16 & 1,408 & 95 & 1,997 & 60 & 1,143 \\
Dec. & 105 & 5,454 & 74 & 3,268 & 90 & 4,202 & 283 & 7,104 \\
Jan. 05 & 342 & 5,532 & 73 & 1,721 & 94 & 2,659 & 77 & 1,976 \\
Feb. & 88 & 1,556 & 128 & 2,796 & 175 & 1,742 & 66 & 2,097 \\
March & 71 & 2,946 & 77 & 3,356 & 21 & 1,189 & 42 & 2,436 \\
April & 60 & 3,662 & 96 & 2,799 & 44 & 1,628 & 160 & 2,070 \\
May & 77 & 2,280 & 104 & 4,277 & 71 & 1,519 & 112 & 1,828 \\
June & 110 & 5,490 & 68 & 4,178 & 86 & 4,363 & 198 & 9,885 \\
July & 91 & 3,491 & 56 & 1,782 & 68 & 1,780 & 44 & 1,923 \\
Aug. & 85 & 2,975 & 69 & 2,441 & 95 & 3,720 & 115 & 2,668 \\
Sept. & 33 & 1,527 & 30 & 801 & 30 & 2,038 & 72 & 6,239 \\
Oct. & 53 & 3,320 & 52 & 2,768 & 45 & 1,304 & 40 & 1,578 \\
Nov. & 90 & 2,969 & 57 & 1,913 & 46 & 1,660 & 63 & 1,540 \\
Dec. & 98 & 4,598 & 81 & 6,357 & 56 & 2,541 & 66 & 1,318 \\
\hline Key. Jn
\end{tabular}

Key: Jan. - January, Feb. - February, Aug. - August, Sept. - September, Oct. - Octoer, Nov. - November, Dec. December

Table 2. Percentage species composition by number and weight for each station (July $2004-2005$ December pooled)

\begin{tabular}{|c|c|c|c|c|c|c|c|c|}
\hline Station & & 1 & & 2 & & 3 & & \\
\hline Family/Species & No. & Wt. (g) & No. & Wt. (g) & No. & Wt. (g) & No. & Wt. (g) \\
\hline BAGRIDAE & & & & & & & & \\
\hline Chrysicthys nigrodigitatus & 26.80 & 31.64 & 20.11 & 28.32 & 19.87 & 33.73 & 29.98 & 40.82 \\
\hline Bagrus docmac niger & 0.37 & 1.24 & 0.81 & 0.38 & 1.74 & 1.02 & 0.54 & 0.30 \\
\hline CENTROPOMIDAE & & & & & & & & \\
\hline Lates niloticus & 3.64 & 3.00 & 2.69 & 1.39 & 3.81 & 2.58 & 1.92 & 1.37 \\
\hline CHARACIDAE & & & & & & & & \\
\hline Brycinus chaperi & 8.32 & 2.14 & 11.81 & 3.45 & 8.36 & 4.62 & 7.84 & 2.53 \\
\hline Brycinus macrolepidotus & 0.18 & 0.36 & 1.47 & 2.87 & 0.08 & 0.14 & 0.48 & 1.56 \\
\hline CHANNIDAE & & & & & & & & \\
\hline Parachanna obscura & 0.49 & 5.17 & 0.81 & 5.63 & 0.50 & 3.40 & 0.36 & 1.27 \\
\hline CICHLIDAE & & & & & & & & \\
\hline Hemichromis fasciatus & 5.05 & 2.03 & 12.38 & 3.44 & 8.61 & 2.90 & 12.39 & 3.70 \\
\hline Sarotherodon galilaeus & 8.81 & 10.83 & 10.59 & 12.58 & 6.62 & 7.97 & 4.67 & 4.59 \\
\hline Tilapia melanopleura & 7.39 & 10.57 & 11.48 & 13.37 & 14.98 & 17.89 & 9.22 & 14.42 \\
\hline Tilapia zillii & 4.93 & 1.19 & 3.82 & 1.15 & 4.14 & 1.21 & 15.96 & 4.03 \\
\hline Tilapia melanotheron & 0.68 & 0.58 & 0.41 & 0.62 & 0.91 & 0.94 & 0.66 & 0.73 \\
\hline Tilapia mariae & 0.31 & 0.81 & 0.32 & 0.49 & 0.17 & 0.64 & 0.36 & 1.07 \\
\hline Tilapia monody & 0.06 & 0.03 & 0 & 0 & 0.25 & 0.16 & 0 & 0 \\
\hline Oreochromis niloticus & 0.62 & 4.06 & 0.98 & 2.94 & 0.99 & 4.65 & 0.54 & 3.85 \\
\hline
\end{tabular}




\begin{tabular}{|c|c|c|c|c|c|c|c|c|}
\hline \multicolumn{9}{|l|}{$\begin{array}{l}\text { Continue Table } 2 \\
\text { CLARIIDAE }\end{array}$} \\
\hline Clarias gariepinus & 0.62 & 5.10 & 1.29 & 6.48 & 0.41 & 1.90 & 0.48 & 10.29 \\
\hline Heterobranchus bidorsalis & 0 & 0 & 0.49 & 2.37 & 0 & 0 & 0 & 0 \\
\hline \multicolumn{9}{|l|}{ CYPRINIDAE } \\
\hline Labeo coubie & 0.06 & 0.06 & 0 & 0 & 0.66 & 0.68 & 0.18 & 0.18 \\
\hline Barbus occidentalis & 5.05 & 1.75 & 3.57 & 0.59 & 12.16 & 3.23 & 5.08 & 1.03 \\
\hline Gara water loti & 0.19 & 0.26 & 0 & 0 & 0 & 0 & 0 & 0 \\
\hline Barilius senegalensis & 0 & 0 & 0.08 & 0.11 & 0.17 & 0.14 & 0.06 & 0.03 \\
\hline Barilius loati & 0.18 & 0.17 & 0 & 0 & 0.47 & 0.29 & 0.18 & 0.14 \\
\hline $\begin{array}{l}\text { HEPSETIDAE } \\
\text { Hepsetus odoe }\end{array}$ & 0.55 & 1.86 & 0.98 & 2.11 & 1.08 & 3.64 & 0.36 & 1.62 \\
\hline \multicolumn{9}{|l|}{ ICTHYOBORIDAE } \\
\hline Phago loricatus & 0 & 0 & 0 & 0 & 0.17 & 0.05 & 0 & 0 \\
\hline \multicolumn{9}{|l|}{ MOCHOKIDAE } \\
\hline Synodontis membranaceus & 0.99 & 2.80 & 0.81 & 3.74 & 0.33 & 0.64 & 0.06 & 0.29 \\
\hline Synodontis nigrita & 0 & 0 & 0.08 & 0.09 & 0 & 0 & 0 & 0 \\
\hline $\begin{array}{l}\text { MALAPTERURIDAE } \\
\text { Malapterurus electricus }\end{array}$ & 0 & 0 & 0 & 0 & 0.08 & 0.60 & 0 & 0 \\
\hline $\begin{array}{l}\text { MORMYRIDAE } \\
\text { Mormyrus rume }\end{array}$ & 0 & 0 & 0.16 & 0.14 & 0.17 & 2.15 & 0.12 & 0.46 \\
\hline $\begin{array}{l}\text { Mormyrus deliciosus } \\
\text { Hyperopisus bebe occidentalis } \\
\text { Marcusenius isidori }\end{array}$ & $\begin{array}{c}0.12 \\
0.56 \\
22.18\end{array}$ & $\begin{array}{l}0.14 \\
4.51 \\
7.36\end{array}$ & $\begin{array}{c}0 \\
0.57 \\
13.29\end{array}$ & $\begin{array}{c}0 \\
2.45 \\
3.36\end{array}$ & $\begin{array}{c}0.49 \\
0.17 \\
11.83\end{array}$ & $\begin{array}{l}0.38 \\
0.21 \\
3.16\end{array}$ & $\begin{array}{l}0.89 \\
0.24 \\
6.75\end{array}$ & $\begin{array}{l}0.58 \\
0.92 \\
2.90\end{array}$ \\
\hline Marcusenius psittacus & 0.06 & 0.05 & 0 & 0 & 0 & 0 & 0 & 0 \\
\hline Gnathonemus senegalensis & 0 & 0 & 0 & 0 & 0 & 0 & 0.06 & 0.11 \\
\hline Gnathonemus cyprinoides & 0 & 0 & 0 & 0 & 0.08 & 0.08 & 0.06 & 0.05 \\
\hline $\begin{array}{l}\text { SCHILBEDAE } \\
\text { Schilbe mystus }\end{array}$ & 1.79 & 2.30 & 1.22 & 1.88 & 0.74 & 1.01 & 0.66 & 1.29 \\
\hline Total no. of spp. that occurred & 26 & & 24 & & 29 & & 27 & \\
\hline
\end{tabular}

Table 3. Seasonal diversity of Ikere Gorge Dam

\begin{tabular}{lcc}
\hline & Wet & Dry \\
\hline Number of species & 24 & 30 \\
Number of individuals & 1958 & 2173 \\
Simpson's index & 0.112 & 0.154 \\
Simpson's index of diversity & 0.888 & 0.846 \\
Simpson's reciprocal index & 8.929 & 6.506 \\
Shannon_H & 2.326 & 2.130 \\
Shannon equitability index (EH) & 0.7318 & 0.6261 \\
\hline
\end{tabular}


Table 4. Annual variations in number of six commercial fish species economic importance from Ikere gorge

\begin{tabular}{lcc}
\hline Fish species & Wet & Dry \\
\hline Chrysichthyes nigrodigitatus & $17.20 \pm 1.40^{\mathrm{a}}$ & $35.07 \pm 7.59^{\mathrm{a}}$ \\
Lates niloticus & $2.80 \pm 0.46^{\mathrm{b}}$ & $4.33 \pm 0.30^{\mathrm{b}}$ \\
Hemichromis fasciatus & $9.57 \pm 2.08^{\mathrm{ab}}$ & $9.43 \pm 1.00^{\mathrm{b}}$ \\
Sarotherodon galilaeus & $8.30 \pm 0.25^{\mathrm{ab}}$ & $7.70 \pm 0.15^{\mathrm{b}}$ \\
Tilapia melanopleura & $13.20 \pm 1.40^{\mathrm{a}}$ & $8.30 \pm 1.25^{\mathrm{b}}$ \\
Tilapia macrocephala & $13.00 \pm 6.79^{\mathrm{a}}$ & $3.63 \pm 0.56^{\mathrm{b}}$ \\
\hline abMeans with different superscript along same column are significantly different $(\mathrm{p}<0.05)$.
\end{tabular}

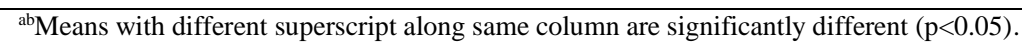

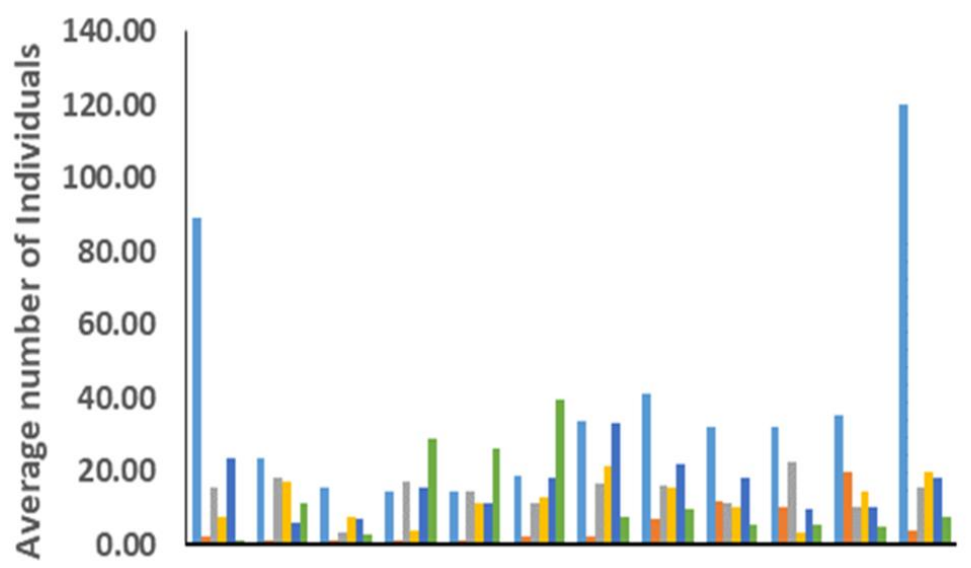

Chrysichthyes nigrodigitatus

Lates niloticus

Hemichromis fasciatus

Sarotherodon galilaeus

- Tilapia melanopleura

Jan Feb Mar Apr May Jun Jul Aug Sep Oct Nov Dec

Months

Figure 5. Seasonal variation in abundance of the six commercial fish species of the gorge

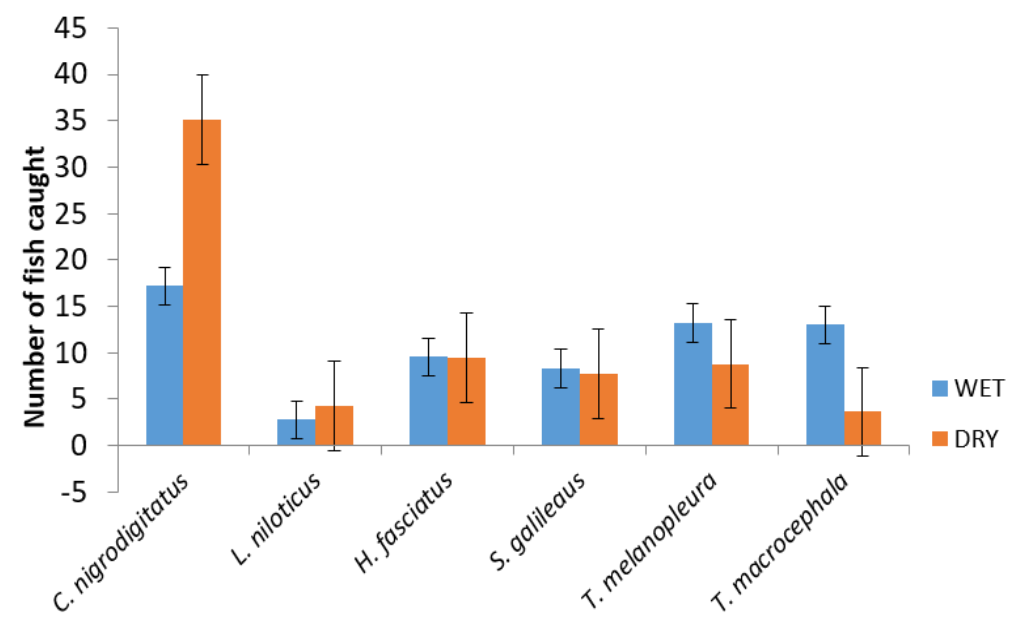

Figure 6. Differences in abundance of individual species in the wet and dry months 


\section{Sex Ratio}

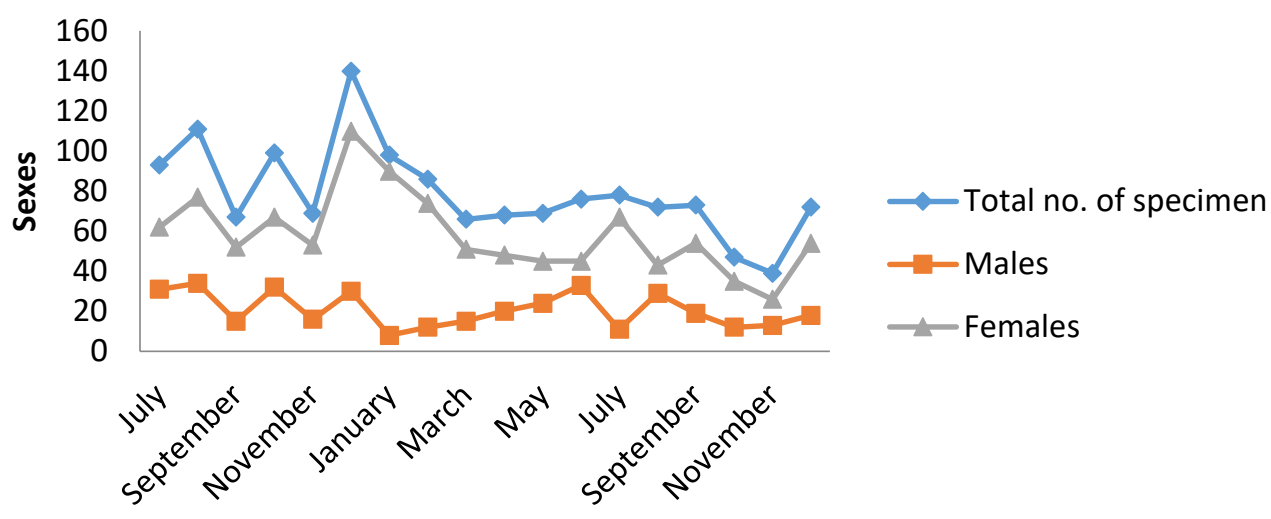

Figure 7. Seasonal variation in sex ratio of Chrysichthys nigrodigitatus

\section{L. niloticus}

L. niloticus commonly known as Niger/Nile Perch is endemic to Ikere River before its impoundment and it was successfully established throughout the gorge after impoundment. A total of 170 specimens of $L$. niloticus were examined whereby 93 were males while 77 were females. Figure 8 shows monthly variation in sex ratio during the sampling period. The result shows that more male predominates throughout the months of the year. However, increase in the number of females were observed during the months of August to December.

\section{T. melanopleura}

Sex ratio of $T$. melanopleura pooled from all four stations was very close to 1 . A total number of 596 specimens of $T$. melanopleura were examined. Throughout the sampling period, the numbers of females were always higher than that of the males (Figure 9). All the examined fish samples had observable gonads. There were fluctuations in the sex ratio from month to month.

\section{Sex Ratio}

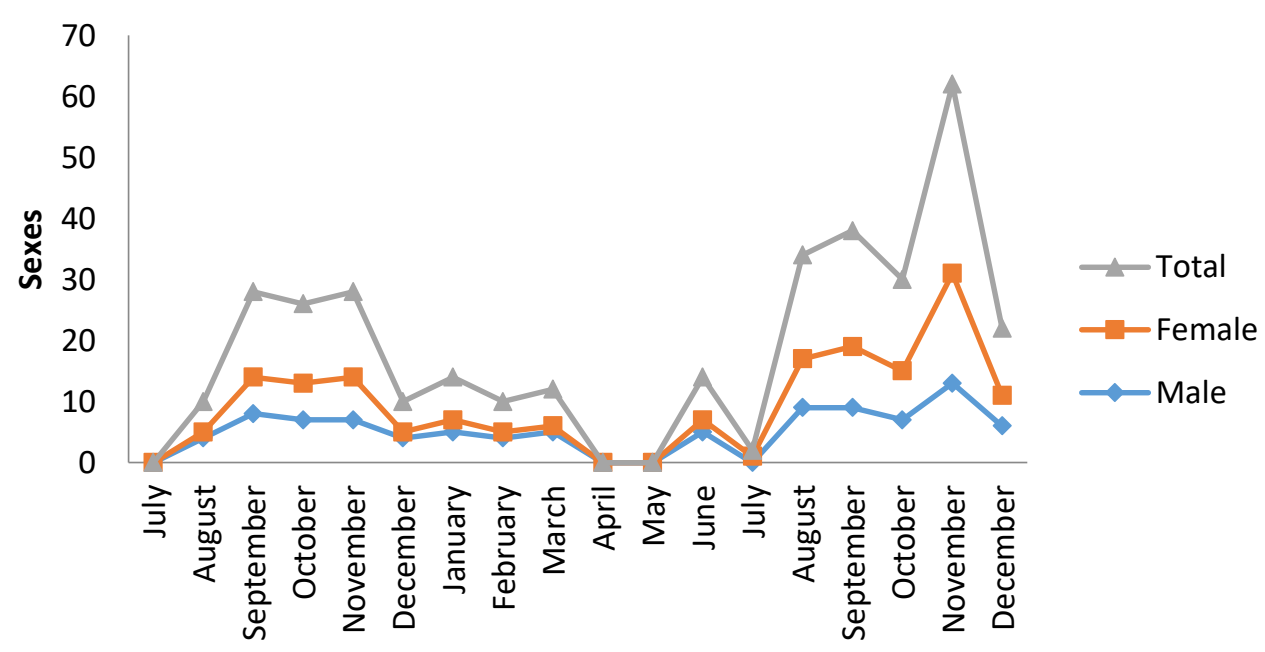

Figure 8. Seasonal variation in sex ratio in Lates niloticus in Ikere Gorge 


\section{Sex Ratio}

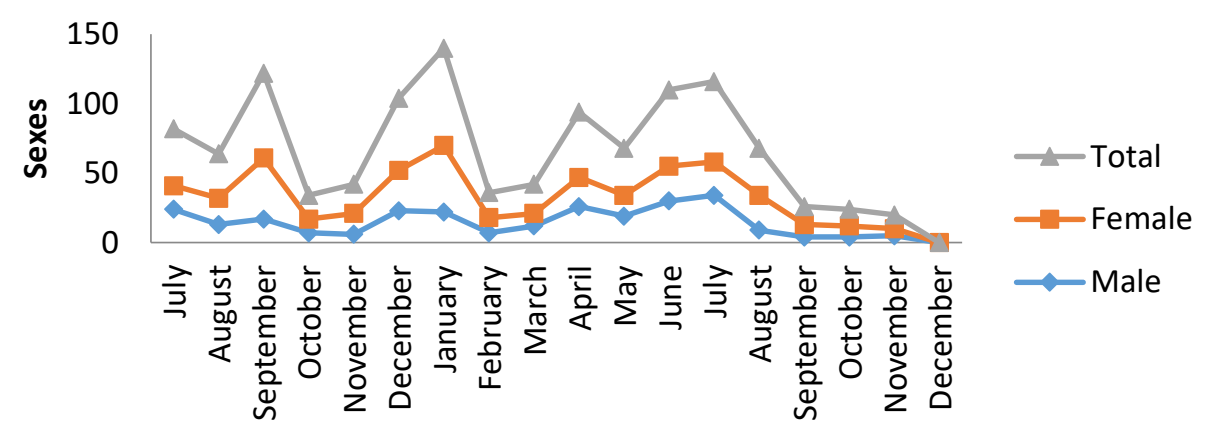

Figure 9. Seasonal variation in sex ratio of Tilapia melanopleura during the study

\section{S. galilaeus}

Figure 10 shows that the sex ratio of $S$. galilaeus from all four stations was very close to 1 of 432 specimens of $S$. galilaeus examined, 154 were males while 278 were females. Most often during the sampling period, the number of females was always higher than that of the males. All the examined fish samples had observable gonads.

\section{DISCUSSION}

Species richness was observed to be higher in the dry months than the rainy months could be attributable to the migration pattern of the fish species and also the stable water condition in this water body during the study. However, high species richness during the dry months did not reflect in the diversity of the fisheries as Simpson and Shannon diversity indices revealed better diversity in the wet months than in the dry months. The seasonal pattern of species richness and abundance recorded in this study is consistent with the findings of Tremain \& Adams (1995). Similar finding was also reported by Olukolajo \& Oluwaseun (2008) that species richness of the fin fishes in Ologe Lagoon was better in the dry than wet season. The study of Ayoola \& Kuton (2009) though similar with the report on species richness and abundance was not similar in terms of diversity as they reported better diversity in the dry months than the wet months.

C. nigrodigitatus, L. niloticus and some species of Cichlids of economic importance were observed in the catch all year round indicating the suitability of the water characteristics for their growth and survival. It could also be attributed to the availability of food to meet their nutrient requirements. This finding

\section{Sex Ratio}

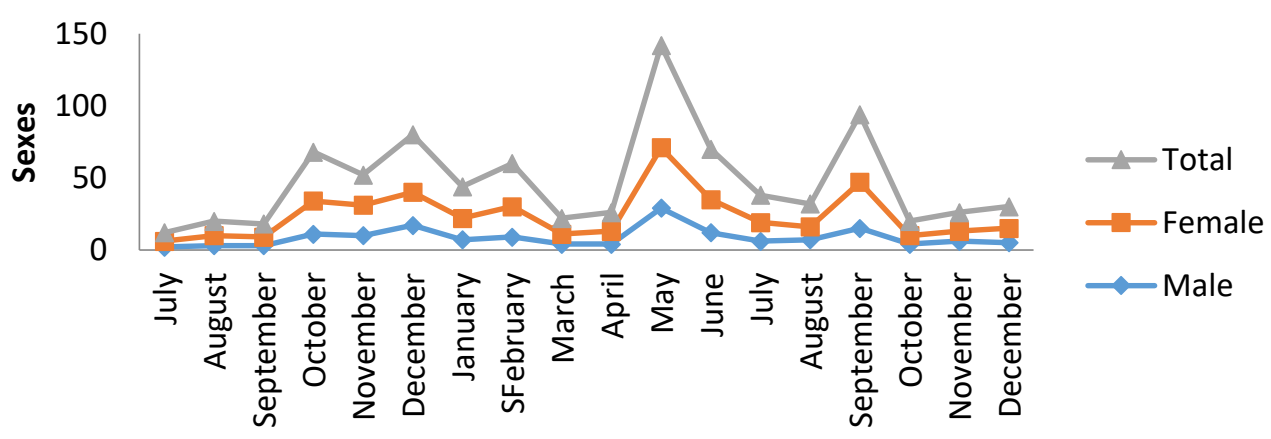

Figure 10. Seasonal variation in sex ratio of Sarotherodon galilaeus 
corroborated with that reported by Oluwajoba $e t$ al., (2017) for the species from the Lagos lagoon. However, in terms of species richness, $C$. nigrodigitatus was more abundant in the dry months than in the wet month which was not the case with the report of Olukolajo \& Oluwaseun (2008) who reported the presence of $C$. nigrodigitatus from Ologe lagoon in South-West, Nigeria only in the wet months of the year. The reasons for this variation may be attributed to the differences in the water quality parameter especially temperature and DO levels of the water body which were consistent within the range for optimum primary productivity, and thus food abundance all year round as in this study.

Other species that were highly abundant at the peak of the dry season is Marcusenius isidoris, though not a commercial fish species, was observed to be high in abundance in the dry months (October - March) and at the onset of the rainy months (April and May) than at the peaks of the wet months. The high abundance of the species in these months could be because the species is not of commercial importance in the study area and thus not overfished. The reason could also be attributed to its spawning behavior as the species is reported to spawn every 5-8 days at sexual maturity (Kirschbaum \& Schugardt, 1995). Akongyuure et al. (2017) reported all year abundance of the species in the Tono reservoir, Northern Ghana.

The Cichlids Hemichromis fasciatus, Sarotherodon galileus, Tilapia melanopleura and Tilapia macrocephala though available in the catch all year round, were more abundant during the wet season than the dry season. This could be correlated to the breeding season of these species which has been reported to occur all year round (Faunce, 2000; Mireku et al., 2016). The result from this study is in agreement with the findings of Ayoola $\&$ Kuton (2009) who reported the presence of the Cichlids all through the year in the Lagos lagoon with the highest abundance in the two seasons. Also, Olapade \& Dienye (2018) reported the distribution and abundance of the Cichlids from February - June in the New Calabar River, Nigeria.

Female predominated throughout the months of the year among the commercial fish species in the area with exception of Lates niloticus. However, there were variations in the monthly sex ratio monitored all through the study as both high and low ratios were observed in both wet and dry months of the study. Thus, the observed variations cannot be attributed to seasonal variations. This was, however, not the case in the study of Komolafe \& Arawomo (2011), who reported higher male to female sex ratio among the Cichlids from Erinle reservoir, Osun State, Nigeria. Skewed sex ratio in favour of one sex has been reported to be a sign of declining wild populations and threat of extinction of the species (Grayson et al., 2015).

C. nigrodigitatus revealed highest preponderance toward female sex in the month of January and lowest ratio of male to female was recorded in June. This showed that more females were present than males and concur with the result of Kusemiju \& Olaniya (1989) who reported a sex ratio of 1 male to 1.27 females in Lagos lagoon while Imevbore (1970) who obtained a sex ratio of 1 male to 1.40 females. This result was however in disagreement with the findings of Akintade et al. (2016) who reported higher male populations of the silver catfish (C. nigrodigitatus) and for Tilapia melanotheron from Badagry creek, Lagos. Offem et al. (2008) also reported similar findings from a water body in Cross River, Nigeria.

\section{CONCLUSION}

The fish fauna from Ikere Gorge showed marked variations in the catch composition from the various locations sampled and between wet and dry seasons. $C$. nigrodigitatus and the Cichlids (H. fasciatus, $S$. galilaeus, $T$. macrocephala and $T$. melanopleura) were present all year round. There were no seasonal variations in the sex ratio of these species, however, preponderance of female was recorded for the species of commercial interest with exception of Lates niloticus.

\section{REFERENCES}

Adeosun, F.I. (2019). The fishes of akomoje reservoir drainage basin in lower River Ogun, Nigeria: Diversity and Abundance. Egyptian Journal of Aquatic Biology and Fisheries, 23(1): 391-402.

Adite, A., Megnisse, H., Gbaguidi, G.A. \& Ategbo, J. (2017). Reproductive biology and life history patterns of the Claroteid, Chrysichthys nigrodigitatus from Man-made Lake in Southern Benin. Journal of Fisheries and Aquatic Science, 12: 106-116. 
Akintade A.O., Edwin C.O. \& Simon E.A. (2016). Length - Weight Relationship, Condition Factor and Sexratio of Fish Fauna in Badagry Creek, Lagos, Nigeria, International Journal of Marine Science, 6(24): $1-8$.

Akongyuure, D.N., Amisah, S. \& Edziyie, R. (2017). Assessment of catch, diversity and abundance of ichthyofauna in the Tono Reservoir, Northern Ghana. International Journal of Fisheries and Aquatic Studies, 5(5): 25-32.

Ayoola, S. O. \& Kuton, M. P. (2009). Seasonal variation in fish abundance and physicochemical parameters of Lagos lagoon, Nigeria. African Journal of Environmental Science and Technology, 3(5): 149158.

Bahrami, K.B., Ghaderi, E. \& Hoseinpour, H. (2015). Growth and reproductive biology of Capoeta damascina (Valenciennes, 1842) from a tributary of Tigris. Iranian Journal of Fisheries Sciences, 14(4): 956-969.

Bracciali, C., Piovano, S., Gianluca, S. \& Giacoma, C. (2014). Seasonal changes in size, sex-ratio and body condition of the damselfish Chromis chromis in the central Mediterranean Sea. Journal of the Marine Biological Association of the United Kingdom, 94(5): 1053-1061.

Dyson, E.A. \& Hurst, G.D.D. (2004). Persistence of an extreme sex-ratio bias in a natural population. Procedure of the National Academy of Science, USA, 101(17): 6520-6523.

Faunce, C.H. (2000). Reproduction of blackchin tilapia, Sarotherodon melanotheron, within an impounded mangrove ecosystem in east-central Florida. Environmental Biology of Fishes, 57: 353-361.

Fryxell, D.C., Arnett, H.A., Apgar, T.M., Kinnison, M.T. \& Palkovacs, E.P. (2015). Sex ratio variation shapes the ecological effects of a globally introduced freshwater fish. Proceedings of the Royal Society of London B, 282: 20151970.

Grayson, K.L., Mitchell, N.J., Monks, J.M., Keall, S.N., Wilson, J.N. \& Nelson, N.J. (2014). Sex ratio bias and extinction risk in an isolated population of Tuatara (Sphenodon punctatus). PLoS ONE, 9(4): e94214.

Gusmão, L.F.M., McKinnon, A.D. \& Richardson, A.J. (2005). No evidence of predation causing female-biased sex ratios in marine pelagic copepods. Marine Ecology Progress Series, 482: 272-298.

Imevbore, A.M.A. (1970). Some Preliminary observations on the ratios and fecundity of the fish in River Niger. In: Visser, S.A (Ed) Kainji Lake Studies. Vol. I, Ecology. Ibadan, Nigeria: Ibadan University Press. Pp 87-98.
Jega, I.S., Miah, M.I., Haque, M.M., Shahjahan, M., Ahmed, Z.F. \& Fatema, K. (2017). Sex ratio, length-weight relationships and seasonal variations in condition factor of menoda catfish Hemibagrus menoda (Hamilton, 1822) of the Kangsha River in Bangladesh. International Journal of Fisheries and Aquatic Studies, 5(5): 4954.

Jiménez-Melero, R., Gilbert, J.D. \& Guerrero, F. (2014). Seasonal variation in the sex ratio of Arctodiaptomus salinus (Copepoda: Calanoida): does it agrees with the "cheaper-sex" hypothesis? Journal of Plankton Research, 36(6): 1413-1418.

Kirschbaum, F. \& Schugardt, C. (1995). Vergleichende Daten zur Fortpflanzungsbiologie von zwei Nilhecht-Arten (Mormyridae). In Greven, H. and Riehl, R. (Eds.) Fortpflanzungsbiologie der Aquarienfische. Bornheim, Germany: Birgit Schmettkamp Verlag. Pp 81-90.

Komolafe, O.O. \& Arawomo. G.A.O. (2011). Observations on the composition, physiological condition and fisheries in Erinle Lake, Osun State, Nigeria. West African Journal of Applied Ecology, 18: 71-78.

Kusemiju, K. \& Olaniyan, C.I.O. (1989). The lengthweight relationship, condition factor and feeding habits of the catfish, Chrysichthys nigrodigitatus (L) in Lagos lagoon, Nigeria. Nigerian Journal of Natural Sciences, 4(1-2): 144-149.

Le Galliard, J., Fitze, P.S., Ferrière, R. \& Clobert, J. (2005). Sex ratio bias, male aggression, and population collapse in lizards. Procedure of the National Academy of Science, USA, 102(50): 18231-18236.

Mian, S., Papree, S.D., Dey, T., Hossain, M.A., Iqbal, M.M., Abol-Munafi, A.B. \& Islam, M.S. (2017). Some Reproductive Aspects of Freshwater Garfish, Xenentodon cancila (Hamilton, 1822) from North-East Bangladesh. Journal of Fisheries and Aquatic Science, 12: 82-89.

Mireku, K.K., Blay, J. \& Yankson, K. (2016). Reproductive biology of Blackchin tilapia, Sarotherodon melanotheron (Pisces: Cichlidae) from Brimsu Reservoir, Cape Coast, Ghana. International Journal of Fisheries and Aquaculture, 8(4): 42-54.

Offem, B.O., Akegbejo-Samsons, Y. \& Omoniyi, I.T. (2008). Diet, size and reproductive biology of the silver catfish, Chrysichthys nigrodigitatus (Siluformes: Bagridae) in the Cross River, Nigeria. Revista de Biologia Tropical, 56(4): 1785-1799. 
Olaosebikan, B. D. \& Raji, A. (1998). Field guide to Nigerian freshwater fishes. New Bussa, Nigeria: Federal College of Freshwater Fisheries Technology. Pp 103.

Olopade, O. A. \& Dienye, H. E. (2018). Distribution and abundance of cichlids in the New Calabar River, Nigeria. Journal of Fisheries, 6(2): 617-622.

Olukolajo, S.O. \& Oluwaseun, K.A. (2008). Seasonal variation in the distribution and fish species diversity of a tropical lagoon in South-West Nigeria. Journal of Fisheries and Aquatic Science, 3: 375-383.

Oluwajoba, E.O., Fakayode, O.S., Oluboba, T.F., Williams, A.B., Ukaonu, S.U. \& Fola-Matthews, O.O. (2017). Seasonal variation in species abundance, diversity and composition of fish fauna in Lagos Lagoon, Nigeria. Nigeria Journal of Fisheries, 14: 1281-1288.
Reichard, M., Polacik, M., Blazek, R. \& Vrtılek, M. (2014). Female bias in the adult sex ratio of African annual fishes: interspecific differences, seasonal trends and environmental predictors. Evolutionary Ecology, 28: 1105-1120.

Tremain, D.M. \& Adams, D.H. (1995). Seasonal variations in species diversity, abundance, and composition of fish communities in the Northern Indian River Lagoon, Florida. Bulletin Marine Science, 57(1): 171-192. 